\title{
Research on the Relationship between Interest Rate and Stock Price in China
}

\author{
Lei Shuangqun
}

Lei Shuangqun, Master of Xidian University, Xi'an city, Shaanxi Province, 710072, email: 2471931663@qq.com, July, 2017

\begin{abstract}
Now China's economy is developing very quickly. China's capital market is on the way to mature. More and more people are interested in the relationship between interest rates and stock market research. Most people think that the stock price will be affected by inflation, interest rates, policies, macroeconomic environment and other factors, particularly affected by interest rate factors. We now have a lot of scholars are studying whether banks adjust interest rates to influence the stock market. This paper will list a theoretical framework describing the relationship between interest rates and stock markets, focusing on the impact of interest rate policy changes on the stock market price. This paper studies the relationship between interest rate and stock market price, not only helps investors to have more reference information in the stock market, but also provides reference value for the central bank to make monetary policy. This paper analyzes the relationship between interest rates and stock prices in the basis of previous studies by using the sample of 2003 to 2014 data in China. We will study the relationship between interest rates and stock indices from empirical research and analysis of short term and long term point of view. This paper will be written according to the theory of knowledge. First, this paper will give a brief introduction about interest rates and equity markets, including how the stock price and interest rates is determined and so on. Then, it will do an empirical research about interest rates and stock prices. The empirical research is mainly used in time-series analysis. Finally, we will sum up the situations and give different advice to different stakeholders.
\end{abstract}

Keywords: Interest rates, stockprice, time series analysis, Shanghai index closed, empirical study

\section{Introduction}

\subsection{Background of the Study}

Today, the development of the stock market has a growing impact on a country's economy, and the stock market is also linked to the wealth of many people. The well-being of many people can be affected by it. Therefore, all factors that affect the stock market will be the focus of attention of economists and investors. Many scholars and experts have been interested in the problem of whether interest rates can affect the stock market or not. Especially with the development of China's capital market, more and more people are buying stocks, so that the ups and downs of stocks will be more and more concerned by Chinese people. This study will provide a reference for investors in investing in the stock market. Only better understanding of the relevant factors of stock prices, investors will make better decisions, thereby reducing investment risks, not in the economy big ups and downs. It is expected that future research will be paid more attention to, and the results will be used by more people as one of the reference factors for investment.

\subsection{Research Questions}

The study sought to answer the following research questions:

1) Whether interest rates can affect the stock market or not?

2) And if the influence exists, how does interest rate change affect stock prices?

\subsection{Research Method}

This paper will adopt time series analysis and regression analysis method, based on China's 2003 rate to Chinese data released in 2014 the people's Bank and Shanghai stock index as the sample data, study the interest rate policy is changed, the stock market's fluctuation and earnings, changes in the stock market is mainly through the Shanghai Stock index closing price calculated the rate of return to reflect. To determine the impact of such events on the stock market and to predict the impact of such events on the stock market in the future

\subsection{Objectives of the Study}

This paper will analyze the relationship between the rate of interest rate changes and stock prices on the basis of previous studies, focusing on the impact of changes in interest rate policy resulting in changes in interest rates, thus affecting the stock market prices. To 2014 data of China's capital market, the Shanghai index closed and interest rate changes by 2003, research and Empirical Analysis on the relationship between interest rate and stock price index from two short and long term.

This paper will be based on the relevant theoretical knowledge, briefly introduces the interest rate and the stock market, including the way that the stock price is decided, and the way that the interest rate is determined. And then makes an empirical study on the interest rate and stock price index. The empirical research is mainly based on time series analysis. Finally, summarize the research situation and give advice to stakeholders. 


\section{International Journal of Science and Research (IJSR) \\ ISSN (Online): 2319-7064 \\ Index Copernicus Value (2015): 78.96 | Impact Factor (2015): 6.391}

\section{Literature Review}

Many scholars have done a lot of empirical research on the relationship between interest rate and stock index. Most scholars believe that the government can change the interest rate policy to influence the stock market. And the stock market situation can also affect how the government makes interest rate policy, the two influence each other.

Li Mingyang and Tang Jianwei (2007) used the monthly data from January 1996 to December 2002 to analyze the one-year deposit interest rate (R) and the Shanghai Stock Exchange Composite Index (SP). The change of interest rate has obvious influence on stock price in the short term. Generally, when the interest rate is lowered, the stock price will rise. But in the medium and long term, the impact of interest rate adjustment on stock prices is uncertain. A month or so before the fall in the interest rate, stock prices have risen or fell.

Zhang Bin (2012) uses the quarterly data of interest rates and stock prices from 1999 to 2010, and uses time series analysis to study the impact of interest rate adjustment on China's stock prices. The results show that there is a lag in the effect of interest rate adjustment on the stock price, so the government should take the time lag into account when implementing the monetary policy, so that we can better achieve the policy objectives.

Ji Hongyun and Cao Yue (2017) used event study method to study the effect of interest rate fluctuation on stock price, and found that interest rate volatility had a significant impact on stock price.

Xin Shibo, Kong Xiangcheng and Singh (2010) effects of interest rate on the stock price by using the regression analysis method, he found that the adjustment of Chinese interest rate to the stock price has a certain effect, but the effect is not very significant. It shows that the influence of monetary policy on the stock market is not strong. The effect of the Chinese government's support for the healthy development of the stock market will be affected by monetary policy.

Fama (1981) found that there was a negative correlation between stock market yield and treasury interest rate. French (1987) draws a conclusion that there is a reverse change between stock return and short interest rate by studying the relationship between interest rate and stock price.

Mahmudul and Gazi (2009) used monthly data from 1988 to 2003 to investigated the relationship between interest rate and stock price for 15 developed and developing countries. They found that interest rates have a significant and negative relationship with share prices for most of the countries. Only six countries are found that changes of interest rateshave a significant and negative relationship with changes of share price.
Chaiporn Vithessonthi and Yaowaluk Techarongrojwong (2012) studied the impact of monetary policy decisions on stock returns by using a sample of 50 repurchase rate announcements of the Bank of Thailand during 2003-2009. They find that the expected change in the repurchase rate has a negative effect on stock returns and the unexpected change in the repurchase rate exhibits no effect on stock returns. They also think that the creditability of the monetary authority has a significant effect on stock prices.

Cengiz Toraman and Çağatay Başarir(2014)investigated the long run relationship between stock market capitalization rate and interest rates by using the time series in Turkey over the period 1998-2012.They found that there is long-run relationship between stock market capitalization rate and interest rates.

YunDaisyLi, Iscan and KuanXu(2010)investigated the impact of monetary policy shocks on stock prices by using structural VAR models with short-run restrictions appropriate for Canada and the United States. They found that the immediate response of stock prices to a domestic tight monetary policy shock in Canada is small and the dynamic response is brief. Whereas in the United States, the immediate response of stock prices to a similar shock is relatively large and the dynamic response is relatively prolonged. They think that these differences are largely driven by differences in financial market openness and hence different dynamic responses of monetary policy shocks between the two countries.

\section{Empirical Analysis}

\subsection{Data}

Although China's reform of the interest rate system is deepening, interest rates are still not fully market-oriented. China is still a country with interest rate control. All kinds of financial institutions basically take the bank customer deposit rate as the benchmark interest rate, and the one-year deposit rate as the core interest rate to calculate the various other interest rates. Therefore, this article regards the one-year deposit interest rate as the core interest rate of interest rate index.

The interest rate is measured by the monthly real interest rate, and the stock index is measured by the monthly average. Because of the financial crisis in 2008, the financial crisis will have a greater impact on the economy. In order to avoid the impact of the financial crisis on the economy, this paper uses data from 2009 to 2015 as a sample. The data are downloaded from flush software, the people's Bank of China and the National Bureau of statistics. An analysis of the short-term effects of rising interest rates on the Shanghai Stock Index 


\section{International Journal of Science and Research (IJSR) \\ ISSN (Online): 2319-7064}

Index Copernicus Value (2015): 78.96 | Impact Factor (2015): 6.391

\subsubsection{Graph analysis}

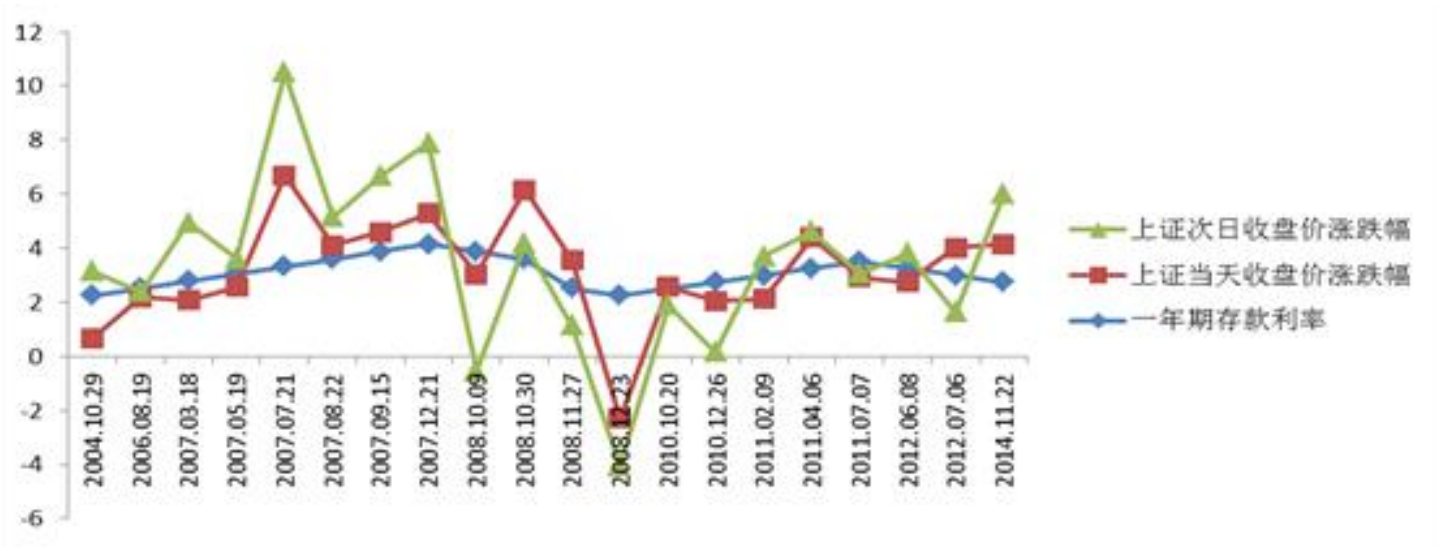

Figure 1: The Shanghai stock index in the two days before and after the change of interest rate

Figure 1 shows that the interest rate has changed by 20 times from 2003 to early 2015. Of these, 13 were raised and 7 were lowered. When the interest rate was raised 13 times, the Shanghai Composite Index rose 5 times that day, down 8 times. The Shanghai Composite Index rose 9 times the following day, and fell once. When the interest rate was lowered 7 times, the Shanghai Composite Index rose 4 times that day and fell 3 times. Shanghai Composite Index rose 2 times the following day, the number of times fell 5 times. In this way, interest rates and share prices have some relevance. As the interest rate rises, the probability of a fall in share prices on the day is large, and the probability of a rise in stock is large when interest rates fall. When interest rates rise, the probability of an upward trend in the stock index the next day is high. Interest rate down, the next day the stock index fell probability of large. From the overall trend of the trend chart, the Shanghai stock exchange price changes on the day and interest rates are showing the opposite direction. But the trend of the Shanghai composite index is always reflected before interest rates change. The next day, and for the Shanghai Composite Index closing prices decline, the trend and the trend of interest rate it has great consistency. When interest rates rise, the Shanghai stock index closed up on the following day. When the interest rate dropped, the Shanghai stock index closed lower on the following day. Based on the above analysis, we can draw the conclusion that when the interest rate rises, the probability of the stock price falling is great. When the interest rate falls, the probability of the stock price rising is very high. The influence of the next day is the same direction. The day's interest rate rose and the stock index rose the following day. The day's interest rate fell, and the stock index fell the following day. This phenomenon shows that before interest rates change, people may have predicted the direction of changes in interest rates, so as to change the stock investment decisions in advance. Their change in investment decisions will affect the stock index. So, on the day of the change in interest rate policy, people have made adequate changes in interest rates. The next day, people will then make corresponding decisions to correct the previous reaction. Therefore, it may lead to the formation of such a trend between the two.

Overall, we can see that the interest rate trend is relatively stable by the data from 2003 to 2015 . However, the stock index volatility. Its direction of change is also uncertain. Its direction of change and interest rate change direction is not strictly reversed. The reasons may be listed as follows: on one hand, the stock price is affected by many factors. The stock price is determined by these complex factors. So that we cannot simply predict the movements of share prices based on changes in interest rates. On the other hand, Stock market in China is not mature, so that changes in stock price may be influenced by people's subjective psychological factors or for speculation.

\subsection{Regression analysis}

Make $\mathrm{x}$ indicate the value after the logarithm of the interest rate, so that $Y$ represents the Shanghai Composite Index, $X$ is the independent variable, and $\mathrm{Y}$ is the dependent variable, and a mathematical model is set up for $X$ and $y: y=\alpha x+c+\varepsilon$ The results are shown in the following table by using E-views software.

Table1: Regression result of interest rate and Shanghai Stock Index

\begin{tabular}{|c|c|c|c|c|}
\hline Variable & Coefficient & Std. Error & t-Statistic & Prob. \\
\hline $\mathrm{X}$ & 0.297272 & 0.274988 & 1.081038 & 0.294 \\
\hline $\mathrm{C}$ & 2.886168 & 0.309804 & 1.081038 & 0 \\
\hline R-squared & 0.060966 & Mean dependent var & 3.216938 & \\
\hline Adjusted R-squared & 0.008798 & S.D. dependent var & 0.218145 & \\
\hline S.E. of regression & 0.217184 & Akaike info criterion & -0.121507 & \\
\hline Sum squared resid & 0.849037 & Schwarz criterion & -0.021934 & \\
\hline Log likelihood & 3.215075 & Hannan-Quinn criter & -0.10207 & \\
\hline F-statistic & 1.168643 & Durbin-Watson stat & 0.976615 & \\
\hline
\end{tabular}

Volume 6 Issue 7, July 2017 www.ijsr.net 


\section{International Journal of Science and Research (IJSR) \\ ISSN (Online): 2319-7064 \\ Index Copernicus Value (2015): 78.96 | Impact Factor (2015): 6.391}

Table1 shows that $\mathrm{R}^{2}$ is 0.060966 , which shows that the fitting degree of the two models is not enough. And there is no strict linear relationship between the two. From the interest rate corresponding to the $\mathrm{P}$ value greater than 0.05 , accept the original hypothesis. That is, there is no strict linear relationship between the interest rate and the Shanghai Composite index in the short time.

\subsection{The long-term effect of interest rate adjustment on the stock index}

\subsubsection{Model}

In 1978, the Co integration test proposed by Engle and Grange was used to determine the existence of economic variables Long-run equilibrium relation. The test has two most commonly used methods: one is the EG two step test, and the other is the Johansen co integration test, which uses different methods of testing in different situations. Since this paper only studies whether there is co integration relationship between interest rate and Shanghai stock index, the EG two step method will be used for the test. EG two step method, the first step is to estimate the equation $\mathrm{y}_{\mathrm{t}}=\alpha_{0}+\alpha_{1} x_{t}+u_{t}$ by OLS and calculate the equilibrium error, and get the $\hat{\mathrm{y}}_{t}=\hat{\alpha} \hat{\alpha}_{t}+\hat{\alpha}_{1} x_{t}, \quad \hat{\boldsymbol{e}}_{t}=y_{t}-\hat{y_{t}}$ The second step: the single integration test of $\hat{\mathrm{e}}_{t}$, if it is stable sequence, so we think that $y_{t}, \mathrm{X}_{t}$ is $(1,1)$ Co integration, if $\hat{\mathrm{e}}_{t}$ is a single whole word, we think that $y_{t}$ $\mathrm{X}_{t}(2,1)$ order Co integration.First, in order to determine the regression equation of unit root test, the Shanghai stock index is plotted. The average of the closing index are showed be the time on the line chart. Model time path is established by E-views analysis.

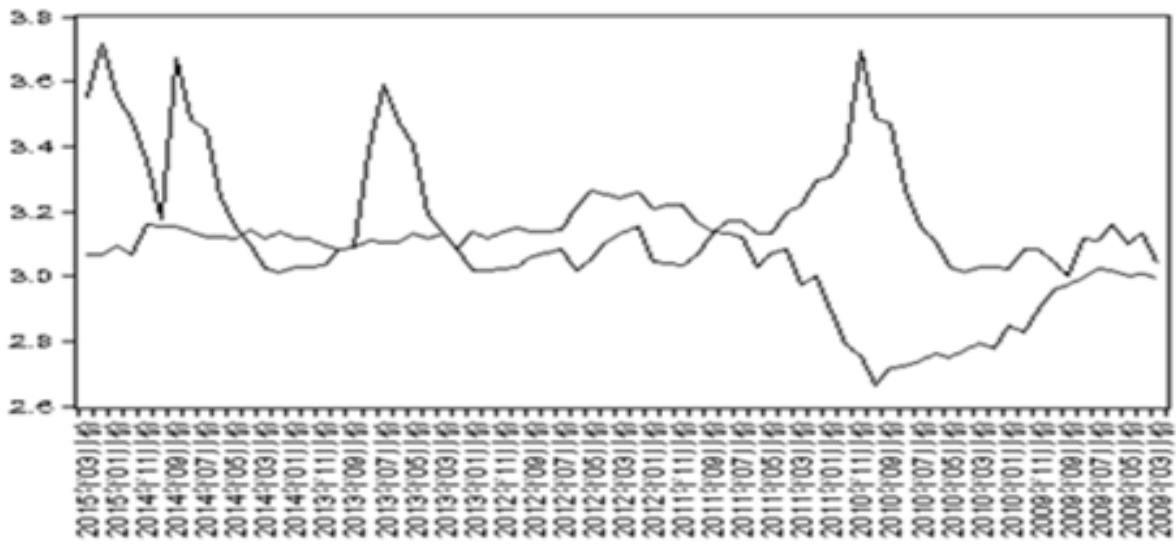

Figure 2: Time series diagram of Lnr and Lnp

It is not difficult to find that there is no obvious negative correlation between Lnr and Lnp. There is a reverse relationship between 2009 and 2011. It can be concluded that they are non-stationary.

\subsubsection{Unit root test}

Next, the unit root test is performed by using the software of E-views. Perform unit root tests on different data separately to see if they are stationary. If the data is not stable, the data of the group needs to be differentiated until the data is stable. Lnr unit root test results are as follows

Table 3: Unit root test results of Lnr

\begin{tabular}{|lc|c|c|}
\hline & t-Statistic & Prob. $^{*}$ \\
\hline Augmented Dickey-Fuller test statistic & -0.276282 & 0.5831 \\
Test critical values: $\quad 1 \%$ level & -2.597476 & \\
& $5 \%$ level & -1.945389 & \\
& $10 \%$ level & -1.613838 & \\
\hline
\end{tabular}

From the above data, we can see that Lnr is less than DW at $1 \%, 5 \%$ and $10 \%$ confidence levels value. Thereby accepting H0, indicating that interest rates are non-stationary sequences. The first order difference and the first difference result are as follows:

Table 4: The result of first order difference of Lnr

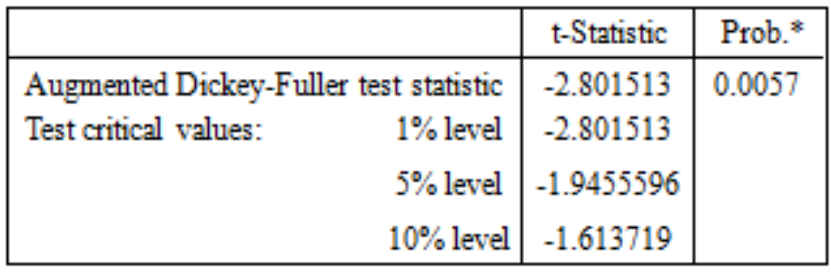

From the above data, it can be seen that the confidence levels of $1 \%, 5 \%$ and $10 \%$ are greater than the first order difference of Lnr DW value: -2.801513 , rejecting the original hypothesis. This shows that the Lnr becomes a stationary sequence after a first-order difference. Thus, the sample can satisfy the prerequisite of co integration test. 


\section{International Journal of Science and Research (IJSR) \\ ISSN (Online): 2319-7064}

Index Copernicus Value (2015): 78.96 | Impact Factor (2015): 6.391

Table 5: Unit root test of Lnp

\begin{tabular}{|lr|r|c|}
\hline & t-Statistic & Prob. $^{*}$ \\
\hline Augmented Dickey-Fuller test statistic & -0.689633 & 0.4148 \\
Test critical values: $\quad 1 \%$ level & -2.597476 & \\
& $5 \%$ level & -1.945389 & \\
& $10 \%$ level & -1.613838 & \\
\hline
\end{tabular}

From the above results, we can see that Lnp is less than DW at the confidence level of $1 \%, 5 \%$ and $10 \%$, which indicates that Lnp is a non-stationary time series and needs to be differentiated. After the first order difference, the results are as follows:
Table 6: Test results after first order difference of Lnp

\begin{tabular}{|lr|r|r|}
\hline & t-Statistic & Prob. $^{*}$ \\
\hline Augmented Dickey-Fuller test statistic & -8.970940 & 0.0000 \\
Test critical values: & $1 \%$ level & -2.597939 & \\
$5 \%$ level & -1.945456 & \\
$10 \%$ level & -1.613799 & \\
\hline
\end{tabular}

From the above data, we can see that after the first difference, the Lnp is set at $1 \%, 5 \%$ and $10 \%$, The letter level is greater than the DW value: -8.970940 , It indicates that it is a stationary sequence, and then the Lnp of the first order difference satisfies the co integration premise.

The above data show that both Lnr and Lnp are I (1) sequences. Next, the residuals are shown below.

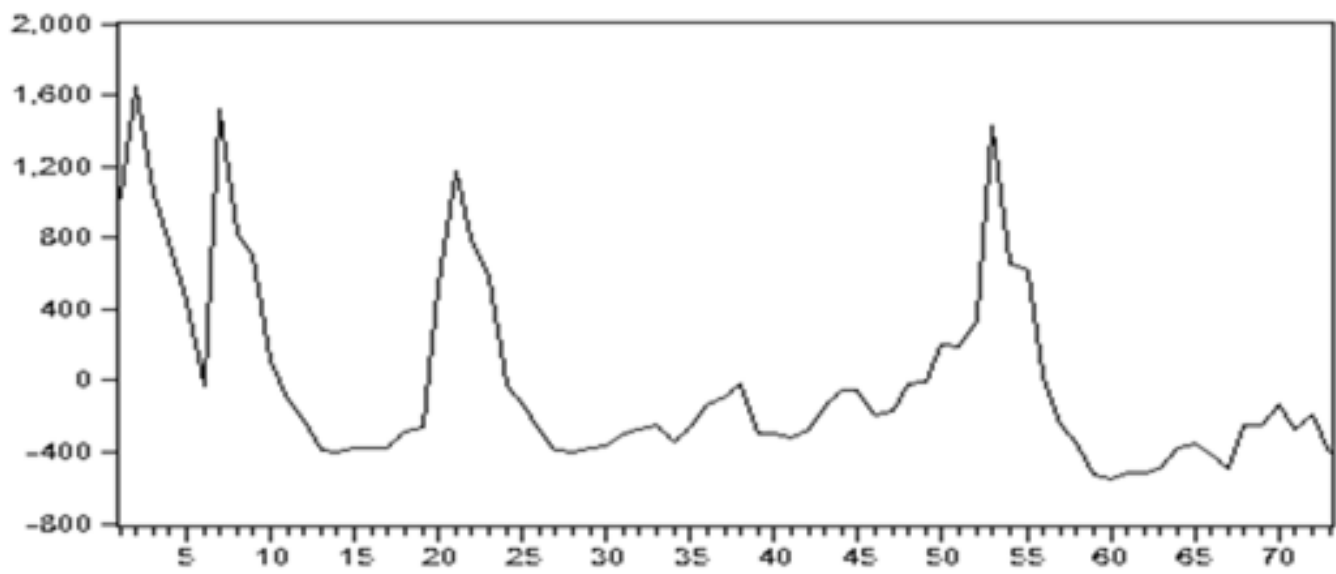

Figure 3: Residual time series diagram

Next, the unit root test of the residuals is performed by using the software of E-views, and the results are as follows:

Table7: Unit root test results of residuals

\begin{tabular}{|c|c|c|c|}
\hline & & t-Statistic & Prob. \\
\hline \multicolumn{2}{|c|}{ Augmented Dickey-Fuller test statistic } & -3.303911 & \multirow[t]{4}{*}{0.0000} \\
\hline \multirow[t]{3}{*}{ Test critical values: } & $1 \%$ level & -3.524233 & \\
\hline & $5 \%$ level & -2.902358 & \\
\hline & $10 \%$ level & -2.588587 & \\
\hline
\end{tabular}

As can be seen from the above data, the DW values are less than $5 \%$ and $10 \%$ confidence levels, slightly greater than $1 \%$ confidence levels. According to the residual graph, you can think of it as a stationary sequence. Thus, there is a co integration relationship between interest rates and the Shanghai average closing index, and there may be a stable relationship between them in the long run.

\subsection{Co integration test}

The first step is building models:

$\operatorname{Ln} p_{t}=c_{0}+c_{1} \operatorname{Ln} r_{t}+u_{t}, \mathrm{t}=1,2,3,4,5 \ldots \ldots . \mathrm{T}$.

According to the regression model, regression was performed with E-views software, and the results of the model were shown as follows.

$\operatorname{Ln} p_{t}=3.656691+(-0.153963) \mathrm{Lnr}_{t}$, Among them, the value of D.W is: 0.369193 , obviously, this shows the auto-correlation of the residual sequence. So, the next step is to revise them under the premise of CO integration.

Establish the model of error correction model:

$$
L n p_{t}=c_{0}+c_{1} \operatorname{Lnp}_{t-1}+c_{2} L n r_{t}+c_{3} L n r_{t-1}
$$

Similarly, the article carries on the regression analysis to the Lnr and the Lnp by using the software of E-views. The results are as follows: 
International Journal of Science and Research (IJSR)

ISSN (Online): 2319-7064

Index Copernicus Value (2015): 78.96 | Impact Factor (2015): 6.391

Table 8: Regression results of $\mathrm{Ln} \mathrm{p}$ and $\mathrm{Ln} \mathrm{r}$

\begin{tabular}{|c|c|c|c|c|}
\hline Variable & Coefficient & Std. Error & t-Statistic & Prob. \\
\hline $\mathrm{X}$ & -0.201943 & 0.334138 & -0.604372 & 0.5477 \\
\hline $\mathrm{C}$ & 0.793431 & 0.420588 & 1.886478 & 0.0636 \\
\hline $\mathrm{X}(-1)$ & 0.197138 & 0.334029 & 0.590182 & 0.5571 \\
\hline$Y(-1)$ & 0.752425 & 0.090098 & 8.351152 & 0.0000 \\
\hline $\mathrm{AR}(1)$ & 0.002240 & 0.156937 & 0.014274 & 0.9887 \\
\hline R-squared & 0.649580 & \multicolumn{2}{|c|}{ Mean dependent var } & 3.175638 \\
\hline Adjusted R-squared & 0.628343 & \multicolumn{2}{|c|}{ S.D. dependent var } & 0.177377 \\
\hline S.E. of regression & 0.108136 & \multicolumn{2}{|c|}{ Akaike info criterion } & -1.543043 \\
\hline Sum squared resid & 0.771757 & \multicolumn{2}{|c|}{ Schwarz criterion } & -1.383699 \\
\hline Log likelihood & 59.77803 & \multicolumn{2}{|c|}{ Hannan-Quinn criter. } & -1.479677 \\
\hline F-statistic & 30.58641 & \multicolumn{2}{|c|}{ Durbin-Watson stat } & 1.976627 \\
\hline Prob.(F-statistic) & 0.000000 & & & \\
\hline Inverted AR Roots & \multicolumn{3}{|c|}{0.00} & \\
\hline
\end{tabular}

Based on the regression results, we can derive

that the model equation :

So some people have the opportunity to make money. What's more, the factors that affect stock prices are very complex and volatile. So it's not surprising.

\section{$\operatorname{Lnp}_{t}=0.79343+0.75243 \operatorname{Lnp}_{t-1}+(-0.20194) \operatorname{Ln} \quad$ 4. Conclusion}

$\mathrm{t}=(1.8865)(8.3512)(-0.6044) \quad(0.5902), \mathrm{R}^{2}=0.6496$,

\section{D. $\mathrm{W}=1.9766$}

In the formula, residuals are represented by the sign of it $\left(u_{t}\right)$. The model is ideal from the significant level, goodness of fit, and D.W of the model. However, because the $\mathrm{P}$ value is not significant, we have to admit the fact that the interest rate is not significant to the stock index. So ultimately we can't get the exact mathematical relationship between interest rates and the stock index in the long run.

\subsection{The summary of Empirical analysis}

Through the above empirical tests, we can know that there is no stable relationship between interest rates and Shanghai Composite Index in the long run. We can't use linear regression model to express the relationship between interest rate and stock index. This conclusion is very different from our usual theory. Previous theoretical knowledge generally assumed that the relationship between interest rates and the stock index presented very fixed, or that the stock price index was related to the expected interest rates. However, the final results show that the relationship between interest rate and stock price index is still uncertain in china. The reason can be listed as follows. It probably because of the following two aspects: One is the China capital market is not mature enough, people have enough change to interest rate expectations or leak. People can get information about changes in interest rates ahead of time. Thus, when interest rates really change, people will no longer change the direction of investment because of this event. Second, China's stock market volatility is seriously divorced from the real economy. This is because China's capital market is not mature, resulting in more prominent phenomenon of speculation. As is often reported in China, those who sell more stocks are often not professional investors, but people who do not know anything about it. The reason for their success is that they are lucky, and it also because the price of the stock market in China is often the price after speculation, which can't reflect the true value.
The conclusion of this study is that in the short run, the change of interest rate will not have a very significant impact on the Shanghai Stock Exchange's closing index. In the short term, there is no significant relationship between the two. In the long run, changes in interest rates, while affecting the Shanghai stock market index, have a linear effect on the relationship. Because of the regression of long-term data, the results show that there is no significant difference between them. This shows again that interest rates do not have a significant impact on the stock index in the short run or long term. Interest rates are only one of the many factors that affect stock prices in China's stock market. And the relationship between the two is uncertain. The main reason may be summarized as follows three points. Firstly, China's capital market is still in a state of immaturity for a long time. China's stock market is still not perfect. Domestic investment varieties are relatively simple, the investment environment fluctuates greatly, the investment market is relatively narrow, and many operational mechanisms are very inefficient. The country's monetary policy and supervision system is not perfect. Investors often appear blind investment or speculation and other irrational behavior. Second, China has long been a policy of interest rate control. Although interest rates are gradually moving towards market in China, They are still in the hands of the government. Therefore, interest rates can not accurately reflect the situation of market supply and demand of funds. There may be supervision is not strict, interest rate policy may exist ahead of disclosure. People are responding to the changing interest rate policy ahead of time, so that when interest rate policy is announced, people do not change their investment decisions. In this way, there is no significant relationship between interest rates and stock index. Third, the macroeconomic situation will have an impact on their relationship. First, it is the economic cycle. As is known to all, people are more willing to invest money in stocks when the economy is in vogue. This will affect the stock price, so that the stock price rose. When the economy is good, people are more convinced that the share price will rise, and that 


\section{International Journal of Science and Research (IJSR) \\ ISSN (Online): 2319-7064}

Index Copernicus Value (2015): 78.96 | Impact Factor (2015): 6.391

the stock price will continue to rise by buying shares. When the economy is bad, many businesses went bankrupt during the recession. People will not have much money to invest the stock market. They will move their funds out of the stock market and move to more useful places. Taking into account the psychological impact of investors, will accelerate stock prices down. Next, it is the government's fiscal policy and monetary policy. These two policies affect the flow of funds and the overall economic situation, such as the direction of investment and financial costs. This will affect the share price. Finally, it is the balance of payments. Today, the economy is moving towards integration and internationalization, and the international balance of payments is becoming a very important factor affecting share prices.

\section{Suggestion}

Our advice to the government is that we need to reduce interest rates and accelerate interest rate liberalization. Let the market itself have more decisions about the direction of the flow of funds. Compared with the United States, China's interest rate market is low. The central bank determines the benchmark interest rate, while the benchmark interest rate is too much to be regulated which results in the interest rate structure between the financial assets is not reasonable. The credit activities of financial institutions and residents are subject to excessive regulation and restriction. There is no linkage mechanism between market interest rate and deposit benchmark interest rate, so that people can't fully use the funds in the real efficient place. And then the efficiency of the use of funds is low. Finally, the stock market is not sensitive to changes in interest rates. Of course, the government can't completely control the interest rate at once, and it needs to be done step by step. Otherwise, the market is suddenly short of control and easily out of control. Therefore, the government needs to release the control of interest rates step by step, and continue to promote market-oriented interest rate reform, so that interest rates can eventually become the "signal" of the market".

The advice to the central bank is that when determining the central bank interest rate policy, they need to give full consideration to reflect this policy may make the market. So as to decide whether to make the interest rate policy changes and if the interest rate policy change. When there is bad reflecting in the capital market, whether the central bank can think an emergency measures this. Therefore, the central bank policy should be fully considered, we must not blindly under the policy.

The recommendations to investors are that investors must be cautious in investing. They need to take full account of the stock market and policy changes and other factors, and not blindly follow the trend. Investors should choose their own investment methods according to their ability to resist risks. They are advised to take full account of risks and potential gains before investing and decide whether to invest or not. Be a rational investor.

\section{References}

[1] Li Mingyang., Tang Jianwei., (2007).Empirical analysis of the effect of interest rate change on stock prices in China.Economic Survey 4, 1006 - 1096.

[2] Zhang Bin., (2012). Empirical Study on the effect of interest rate adjustment on stock prices. Cooperative economy and Science and Technology 12,8 - 446.

[3] Xin Shibo., Kong Xiangcheng.,Xin Qian.,(2010). Analysis of the effect of interest rates on stock prices in China,China Management Information 23, 1673 0194.

[4] Ji Hongyun., Cao Yue., (2017), Analysis of the influence of interest rate change on stock price in China. Finance Vertical and Horizontal 10, 32 - 1034.

[5] Fama, E. F., (1981). Stock Return, real activity, inflation, and money. American Economic Review 71(4), 545-65.

[6] French KR., Schwert GW., Stambaugh RE.,(1987). Expected stock returns and volatility. Journal of Finance Economics 19, 3-29.

[7] Mahmudul, A., Gazi Salah, U., (2009). The relationship between interest rate and stock price: Empirical evidence from developed anddeveloping countries. International Journal Of Business And Management 4(3), 43-51.

[8] Chaiporn V., Yaowaluk T.,(2012). The impact of monetary policy decisions on stock returns:Evidence from Thailand. Journal of International FinancialMarkets, Institutions \& Money22 (2012) 487-507.

[9] Cengiz Toraman.,Çağatay Başarir.,(2014).The long run relationship between stock market capitalization rateand interest rate: co-integration approach. ProcediaSocial and Behavioral Sciences143, 070 1073.

[10] YunDaisyLi., Iscan., KuanXu.,(2010). The impact of monetary policy shocks on stockprices: Evidence from Canada and the United States. Journal of International Money and Finance 29, 876-896. 